Article

\title{
Religious Contexts and Violence in Emerging and Traditional Immigrant Destinations
}

\author{
Casey T. Harris ${ }^{1, *}$, Ben Feldmeyer ${ }^{2}$ and Raymond Barranco ${ }^{3}$ \\ 1 Department of Sociology and Criminal Justice, University of Arkansas, 211 Old Main, \\ Fayetteville, AR 72701, USA \\ 2 College of Education, Criminal Justice, and Human Services, University of Cincinnati; \\ Cincinnati, OH 45221, USA; feldmebn@ucmail.uc.edu \\ 3 Department of Sociology, Mississippi State University, Bowen Hall 456 Hardy Road, \\ Mississippi State, MS 39762, USA; RBarranco@soc.msstate.edu \\ * Correspondence: caseyh@uark.edu
}

Received: 13 March 2018; Accepted: 5 April 2018; Published: 8 April 2018

\begin{abstract}
Amidst both a resurgent interest in the impact of religion on social problems like crime, including its contextual effects, as well as scholarship directed toward the immigration-crime intersection, the current study examines how different religious traditions impact known violent offending uniquely in traditional versus emerging immigrant destinations. To do so, we employ negative binomial models regressing homicides, robberies, and aggravated assaults on adherence to three major religious traditions (mainline Protestant, evangelical Protestant, and Catholic), as well as immigration and other key macro-structural controls. We disaggregate our analysis for three types of United States counties in 2010: emerging, traditional, and other immigrant destinations. We find that religious traditions vary in their relationship with known violence across destination types: Catholic adherence is protective against crime (net of controls) only in established immigrant destinations, but evangelical Protestant adherence is associated with higher levels of robbery and aggravated assault in the same locales. Religious adherence has no links to violence in emerging immigrant destinations. Broadly, our findings reveal that the religious context is an important part of the evolving story of immigration, though it is multifaceted and context-dependent.
\end{abstract}

Keywords: immigration; religion; violence; immigrant destinations

\section{Introduction}

\subsection{Overview}

Across the last half century, the scientific study of religion and its intersections with crime, deviance, and crime control policy has undergone massive growth. More recently, the early decades of the 21st century have also seen two largely independent literatures emerge within sociology, examining the ways that (1) religious contexts and (2) immigration are related to macro-level patterns of violence. Research on religious contexts and crime-which remains small but growing-has generally shown that religious adherence is associated with lower rates of violence (Lee 2006; Lee and Bartkowski 2004; Ulmer and Harris 2013). Likewise, a separate and generally much larger body of scholarship on immigration and crime consistently reports that places with larger immigrant populations have either similar or lower levels of violence than places with relatively few foreign-born residents (Martinez 2002; Ousey and Kubrin 2009; Sampson 2008; Shihadeh and Barranco 2010). In sum, high levels of immigration and religious affiliation both appear to make communities safer or (at worst) no more crime-prone than comparable places with less immigration or religious adherence. 
However, two issues remain unresolved. First, research has yet to fully explore the relationships between religious adherence and immigration, especially as they intersect to shape macro-level patterns of crime and violence. Indeed, religion has long been viewed as a distinct cultural force within communities, purveying moral norms of behavior backed by sacred meanings and occasional sanctions (Smith 2003). Focusing on immigrant populations, both theoretical and empirical research on religious transmission across countries (Van Tubergen 2006), as well as scholarship on immigrant assimilation, suggest that the church is a central institution of support in immigrant communities that reinforces traditional value systems and strengthens social networks (Hirschman 2004; Yang and Ebaugh 2001). Likewise, from a related structural position, the "immigrant revitalization" perspective suggests that attachment to pro-social institutions (including religious ones) among foreign-born individuals helps to stabilize immigrant communities in ways that strengthen informal social control and insulate them from social problems, including crime (Bursik and Grasmick 1993; Martinez 2002; Shihadeh and Winters 2010). Yet, few studies have empirically examined these relationships to identify the potential connections between immigration, religious contexts, and crime (for an exception, see Harris and Feldmeyer 2015).

Second, there is a need to better contextualize the effects of both community religious permeation and immigration on crime by exploring how these relationships vary across (a) different types of religious adherence and (b) unique immigrant contexts. Although research on religion and crime at the macro-level remains underdeveloped, preliminary findings suggest that adherence to specific religious traditions ${ }^{1}$ and includes such denominations as Episcopal, Presbyterian, and Methodist. may have unique effects on community rates of crime and related social problems (Beyerlein and Hipp 2005). Similarly, research on the immigration-crime nexus observes that immigration impacts violence in unique ways depending on a community's history of immigrant settlement (Painter-Davis 2016; Ramey 2013; Shihadeh and Barranco 2013). In particular, immigrants settling in the U.S. over the past decade have increasingly bypassed traditional urban points of entry in favor of towns, rural areas, cities, and states with little or no established history of foreign-born settlement (Frey 2006; Singer 2004; Shihadeh and Barranco 2010, 2013; Zuniga and Hernandez-Leon 2005). How such a demographic shift intersects with patterns of religious adherence and, in turn, crime remains wholly unexplored.

Taken together, empirical research is needed that (1) establishes the ways in which immigration and religious contexts shape community patterns of crime; and (2) identifies whether these macro-level relationships vary across different types of immigrant contexts or are contingent upon the type of religious adherence present in a community. The current study seeks to fill this gap by examining the relationships between mainline Protestant, evangelical Protestant, and Catholic adherence and rates of serious violent crime across emerging, established, and other immigrant destinations throughout the United States in 2010.

\subsection{Religion and Crime at the Macro-Level}

Social scientists interested in patterns of crime across communities have overwhelmingly focused on structural features of communities, especially measures of disadvantage, to explain differences in crime across place. Over the past several decades, measures of poverty, unemployment, and mobility have been found to be "among the strongest macro-level predictors of crime" (Pratt and Cullen 2005, p. 397; see also Peterson and Krivo 2005). Increasingly, however, prominent scholars, both within the sociology of religion and criminology, have supplemented and extended such research by examining

1 Religious traditions are typically delineated using the RELTRAD scheme (Steensland et al. 2000), in which denominations are grouped into Catholic, Jewish, evangelical Protestant, mainline Protestant, black Protestant, and "other" religious traditions. For clarity, evangelical Protestantism emphasizes a personal relationship with Christ, the inspiration of the Bible, the importance of sharing faith with non-believers (i.e., evangelism), and is usually seen as being more theologically and socially conservative. Examples of such denominations include Baptist, Pentecostal, and Church of God. In contrast, mainline Protestantism is considered theologically liberal or moderate (though this "tradition" is quite a bit more heterogeneous than evangelical Protestantism), 
the way macro-level patterns of crime are shaped by cultural and civic characteristics of communities, especially religious ones, which are thought to buffer against crime and other social problems as suggested by sociological scholarship (Bursik and Grasmick 1993; Sampson 2013).

For example, religious organizations and their adherents promote cultural belief systems emphasizing morality, benevolence, and support for laws and societal rules that should work to reduce crime (Hirschi and Stark 1969) and, in some cases, may encourage intergroup contact, civic engagement, and informal supervision that reduces offending (Putnam 2000). Likewise, drawing theoretically from classic Chicago School themes, civic community perspectives stress that local religious organizations augment social networks and aid in the production of social capital that can, among other things, foster informal social control among community residents (Lee 2006) in ways consistent with Putnam (2000) emphasis on "bridging" residents of communities through faith works. Moreover, systemic models of social disorganization suggest that the permeation of religion at the macro-level strengthens social ties (both parochial and private) by increasing community-wide institutional engagement and social interaction (Bursik and Grasmick 1993). In turn, these social networks can increase community levels of collective efficacy and guardianship in ways that reduce crime (Lee and Bartkowski 2004; Tolbert et al. 1998, 2002), or even increase tangible social, economic, and material support (e.g., assistance with food, clothing, finances, transportation, housing, counseling, as well as physical and mental health care) that helps counter the disadvantages residents face and that are commonly linked to strain and crime (Merton 1938). Indeed, research by Johnson et al. (2000) demonstrates the critical role played by religion, especially in disadvantaged contexts, in reducing criminal behaviors. Finally, drawing from institutional anomie theory, greater religious adherence is thought to decrease crime rates by strengthening the role of non-economic institutions that provide normative control in communities (Chamlin and Cochran 1995; Messner and Rosenfeld 1994) or that provide conventional social bonds, as well as cultural belief systems that emphasize morality, benevolence, and support for laws and societal rules consistent with social bonding theories of crime (Hirschi and Stark 1969).

In support of these theoretical perspectives, research to-date finds that places with a greater presence of religious adherents have lower rates of juvenile homicide (Lee and Bartkowski 2004) and violent crime more broadly, net of other key structural features (Harris and Feldmeyer 2015; Lee 2006, 2008; Ulmer and Harris 2013). Yet, sociologists have long recognized that some religious groups (namely mainline Protestants and Catholics) are more likely to promote "bridging social capital" that enhances social networks, strengthens between-group ties, and encourages community-wide coordination (Sampson and Raudenbush 1999) than other religious groups (namely evangelical Protestants), which can foster "bonding social capital that creates strong ties among in-group members but does less to encourage wider outreach to the community" (Putnam 2000). Consistent with such expectations, several studies report either null or negative associations between mainline Protestant or Catholic adherence and crime, but find that evangelical Protestant adherence is positively associated with violence (e.g., Beyerlein and Hipp 2005; Desmond et al. 2010; Ellison et al. 2003; Shihadeh and Winters 2010). However, outside of these few exceptions, research offers little insight about macro-level religion and crime relationships, especially across distinct religious traditions.

\subsection{Religion and Crime in Immigrant Destinations}

Paralleling this macro-level religion-crime literature, questions remain as to how religious adherence, especially to specific traditions, is linked to crime in different types of communities, including those into which immigrants migrate. Indeed, there is a growing consensus among social scientists that immigration does not contribute to crime in the manner often espoused in political and public rhetoric, and, in fact, is often negatively associated with community levels of violence (for a recent meta-analysis, see Ousey and Kubrin (2018)). In turn, scholars have suggested (but rarely tested) that religion may be a key protective mechanism through which immigration insulates communities from crime (Harris and Feldmeyer 2015; Shihadeh and Winters 2010). Certainly 
the immigrant assimilation literature and leading "immigrant revitalization" perspectives emphasize religious institutions and their adherents as sources of social support, familiar cultural traditions, and social ties that help new (and not so new) immigrants overcome the barriers they face in their new communities (Lee et al. 2001; Portes and Rumbaut 2006; Yang and Ebaugh 2001). Overall, then, the religious context may provide a "shot of morality" (Harris and Feldmeyer 2015, p. 229) or function as a central spoke in the "umbrella of social control" (Shihadeh and Winters 2010, p. 628) that insulates immigrant communities from social problems.

Yet, beginning around the turn of the 21st century, immigrant settlement within the United States began to expand outside the traditional, urban locales near the border in favor of emerging destinations within counties and states without much history of immigrant reception, including smaller cities, towns, suburbs, and rural areas (Frey 2006; Lichter and Johnson 2009; Shihadeh and Barranco 2010). Certainly, the story of immigrant population growth has been a profoundly uneven one in which "the immigrant population more than doubled in 19 states, many of which had little prior experience with the foreign born" (Terrazas 2011, p. 1). Still other communities fall somewhere in between, experiencing some small but steady immigrant population growth different than in traditional or emerging destinations. Central to our purposes here, the result is that immigrant communities differ greatly in their histories of settlement in ways that might condition the relationship between religion and crime at the macro-level, especially as it regards the three largest religious traditions: Catholic, evangelical Protestant, and mainline Protestant.

Indeed, there are good reasons to suspect that religious adherence as a milieu effect may operate differently across immigrant communities. First, a large proportion of immigrants arriving over the past several decades are of Hispanic origin, with many having long participated in the Catholic faith in their countries of birth (Navarro-Rivera et al. 2010; Pew Hispanic Center 2007, 2014). As such, they may look to the Catholic Church for help in organizing their social lives and for orienting themselves in their new communities. However, this may work differently in emerging destinations as compared to more traditional ones, with competing expectations as to whether Catholic adherence protects against crime more in one or the other types of contexts. On the one hand, emerging immigrant locales have fewer alternative civic organizations for new Hispanic immigrants (Shihadeh and Winters 2010) and, as such, the Catholic Church may function as a vehicle for assimilation and protection in more pronounced ways in such places. On the other hand, traditional immigrant communities have longer histories of Hispanic settlement and a larger "critical mass" of Catholic adherents (and more established institutions and places of worship). As a result, the Catholic Church may be more established as a pillar of the community in traditional immigrant destinations and may be better positioned to provide social capital and protective benefits to help minimize crime in established immigrant communities.

Second, while previous research has found evangelical Protestantism to be positively associated with crime (Beyerlein and Hipp 2005; Shihadeh and Winters 2010), it may have stronger effects in some types of immigrant communities than others. For example, the relative presence of evangelical adherents has been linked to greater bonding capital that promotes in-group solidarity and insularity and that creates barriers to forming broader community-wide social networks (or exacerbates tension with outgroups that undermines cooperation and social control efforts across groups). As such, we might expect evangelical Protestantism to yield few (if any) benefits to crime prevention in emerging immigrant destinations because few immigrants arrive in the U.S. already attached to or seeking connections with such institutions. At the same time, evangelical adherence may not be associated with increased rates of crime in emerging immigrant communities, simply because the kinds of in-group/out-group tension suggested by prior research (e.g., Beyerlein and Hipp 2005) have not developed given the relatively recent presence of immigrants in such communities. In traditional immigrant destinations, however, evangelical adherence might be positively associated with crime, as observed in prior research, because the longer history of immigrant settlement and more established religious participation patterns engender more of the bonding capital dynamics that undermine community social control capacity (Putnam 2000). 
Finally, there are reasons to suspect that mainline Protestantism may either (a) be negatively associated with crime in both emerging and traditional immigrant destinations; (b) be negatively associated with crime only in traditional immigrant communities; or (c) have little or no impact on crime in either traditional or emerging immigrant destinations. Specifically, mainline Protestant denominations are thought to produce more bridging capital than evangelical adherence at the macro-level, suggesting that such adherence is negatively associated with crime in all contexts (see Beyerlein and Hipp 2005). However, mainline Protestants represent only a small fraction of the religious landscape compared to evangelical Protestants (see Table 1 below) and are especially heterogeneous in their community outreach, with only a small proportion that are classified as "civically engaged" (Tolbert et al. 1998; see also Lee and Bartkowski 2004). As such, mainline Protestantism may be negatively associated with crime only in traditional immigrant destinations where civic outreach has had time to extend to the foreign-born population. In contrast, such adherence may also offer little crime-prevention benefits, regardless of destination type, because adherence to other religious traditions (e.g., Catholicism) matters more.

In sum, there are reasons to suspect that adherence to specific religious traditions could link to either higher or lower community crime rates (or null relationships) and that these associations may differ widely across established and emerging immigrant destinations. Yet, to our knowledge, only a single study has directly examined the link between religious contextual characteristics and crime in immigrant destinations. Using year 2000 Latino homicide victimizations, Shihadeh and Winters (2010) found that Catholic participation is unrelated to Latino homicide in emerging and traditional destinations, while mainline Protestant adherence is positively associated with rates of Latino homicide in emerging destinations (but not in traditional communities). Although it offers numerous contributions to this line of inquiry, their analysis is limited to the assessment of Latino homicide victimization and uses year 2000 data. Thus, our goal here is to extend the seminal work of Shihadeh and Winters (2010) and the broader religion-crime literature to examine how various types of religious adherence predict serious violence (both lethal and non-lethal) in emerging as compared to established immigrant communities. We now describe the parameters of the current study.

\section{Materials and Methods}

\subsection{Sources of Data}

Data for the current study are drawn from three sources. First, we utilize the Uniform Crime Reporting (UCR) program's county-level database of offenses known to law enforcement for the years 2009-2011 that record the number of offenses reported or detected by the police for each agency. Second, we pair our crime data with measures of macro-structural characteristics, including immigration and key control variables, derived from the United States Census summary files and American Community Survey for the year 2010. Third, characteristics of the religious context are drawn from the Religious Congregations and Membership Survey (RCMS) for the year 2010. The RCMS provides a county-by-county enumeration of religious bodies in the U.S. as tallied by the National Council of Churches and the Glenmary Research Center with each participating religious body supplying the number of churches, full members, adherents (affiliated members of a congregation or those who regularly attend services), and other church population estimates (Jones et al. 2002).

Though we are unaware of any viable alternative data sources for assessing the link between the religious context and crime across a large number of units at the macro-level, we recognize several caveats in using the RCMS. One limitation is that it likely undercounts some religious adherents, especially minorities (Finke and Scheitle 2005), even though the 2010 RCMS data have devoted considerable effort to alleviating this problem relative to prior data collection 
efforts (Association of Statisticians of American Religious Bodies 2012). ${ }^{2}$ Additionally, the RCMS data cannot capture degrees of participation or more nuanced aspects of adherence (e.g., level of involvement, belief, attachment, or race/ethnic-specific adherence). We acknowledge that these are important nuances impacting the religious milieu in a given community, and that should be explored. As such, we highlight these in our concluding discussion as important avenues for future research. Nevertheless, we rely on the population of religious adherents because it is an established measure of the institutional permeation of religion in a locale and because it captures the type of collective adherence that is thought to shape normative cultural milieu and foster social control, as suggested in prior empirical research (see Beyerlein and Hipp 2005; Ulmer and Harris 2013).

\subsection{Units of Analysis}

Our unit of analysis is the county, which we use for three reasons. First, counties are the smallest aggregate units for which religious contextual data via the RCMS are available. Although some scholars might prefer smaller study units, many of the theoretical frameworks supporting macro-level research (e.g., civic community, social disorganization, institutional anomie) are not restricted to neighborhoods or smaller units, but have in many instances been applied to larger units of varying sizes (e.g., counties, states, and even nations) (see for example Lee and Bartkowski 2004; Ogsood and Chambers 2000). Second, counties provide a large enough sample size to include an adequate number of covariates while retaining statistical power to detect effects. Third, most prior research examining religion and crime at the macro-level has used counties as a unit of analysis and has illustrated that they are well-suited for identifying macro-level patterns of religious participation (e.g., Lee and Bartkowski 2004; Lee 2006, 2008; Shihadeh and Winters 2010).

We restrict our sample of counties to those that provide violent crime estimates to the FBI's UCR program for the period of 2009-2011, have a total population of at least 10,000, and at least 1000 foreign-born persons residing within them in $2010 .^{3}$ There are approximately 1359 counties meeting these criteria, together covering the majority of the U.S. population and violent crime in the United States (Federal Bureau of Investigation 2010). Following prior research (Harris and Feldmeyer 2013; Lichter and Johnson 2009), we partitioned these counties into "traditional" and "emerging" immigrant locales: traditional destinations were defined as those counties in which the foreign-born population in 1980, 1990, and 2000 exceeded the national averages at each point, while emerging destinations were delineated as those counties where the percentage of foreign-born persons was less than the national average in 1980 and 1990, but where the foreign-born population grew by more than 100 percent between 1990 and 2000. All counties not fitting into either of these two categories but which met our basic population requirements were considered "other" immigrant destinations and are presented alongside our findings for the traditional and emerging destinations as a point of comparison. Our final sample includes 320 traditional, 135 emerging, and 649 other immigrant destinations. ${ }^{4}$

2 Some attempts have been made to correct the undercount problem in the 2010 RCMS, but minorities in marginal denominations (or those which are non-denominational) are often overlooked because they lack resources for data collection efforts. Though few alternative data sources exist, it is important to keep in mind that some adherents may still be missing despite efforts to capture them. This also hinders our ability to construct a longitudinal database for examining change over time, since there is an issue of reliability across multiple points.

3 We also ran a full battery of diagnostic tests to assess the impact of influential cases in our sample of counties. No outliers were identified using standard DFFIT cut-off points, and Cook's D tests revealed several potential outliers that did not substantively influence the results when removed from supplemental models. We also conducted Breusch-Pagan/Cook-Weisberg tests and visually assessed plots of residuals versus fitted values, which revealed little indication of heteroskedasticity. In addition, we inspected the geographic distribution of counties to assess whether spatial autocorrelation could be a problem. Preliminary analyses using Moran's I statistics revealed no significant effects of spatial autocorrelation in our models with many spatial "islands" appearing in the subsamples of emerging, traditional, and other immigrant destinations.

4 None of our counties were classified simultaneously as emerging, established, or "other" immigrant destinations (see Painter-Davis (2016) for a discussion of this issue). Alternative methods of defining immigrant destinations resulted in some of the counties in our "other" category being reclassified as "emerging" or (in fewer cases) "traditional" (see Harris and Feldmeyer (2013); Painter-Davis (2016) for similar alternative specification tests). Our primary results 


\subsection{Dependent Variables}

The dependent variables for this study are county-level homicide, robbery, and aggravated assault counts centered on the year 2010. Following prior research, violence counts are averaged across a three-year period (2009-2011) to provide greater stability to our measures as well as to ensure adequate offense counts for statistically rare offenses like homicide. ${ }^{5}$ Data drawn from official justice agency sources are subject to well-known critiques, namely that they (a) underestimate true levels of offending and (b) are confounded to some degree by enforcement efforts, attention, and policies of state and local police. We recognize these caveats, but note that the current study's measure of crime includes "offenses known" to law enforcement (through report/detection), rather than only those that result in arrest. Our analysis also focuses on established measures of serious violence (especially homicide and robbery) that are more reliably measured and less subject to police discretion or enforcement practices across locales (Lafree et al. 2008; Steffensmeier and Haynie 2000). Finally, we include a control for police force size using a measure of logged police per capita.

Although some macro-level studies of immigration and crime have examined race/ethnic-specific crime rates (e.g., Harris and Feldmeyer 2013; Martinez et al. 2010; Shihadeh and Barranco 2010), many others do not (Feldmeyer et al. 2015; Lyons et al. 2013; Ousey and Kubrin 2009; Ramey 2013; Wadsworth 2010). The current study relies on overall or total county rates of violence for several reasons. First, race/ethnic-specific crime data that code Latinos separately from Whites and Blacks are not widely available for all of the offenses and U.S. counties examined here. Second, those that do are generally limited to either a single offense, like homicide (e.g., the mortality files from the Centers for Disease Control; Supplemental Homicide Reports, see Shihadeh and Winters (2010)), or to arrest figures from a few select states (e.g., California or New York databases-see Ulmer and Harris (2013)). Last, prior research has already provided analyses of religious context and Latino homicide victimization in immigrant communities (Shihadeh and Winters 2010). Yet, questions remain about whether these relationships apply to (1) serious violent offending; (2) other non-lethal measures of violence (e.g., robbery and aggravated assault); and (3) broader or overall populations (including but not limited to Latinos) in both new and established destinations.

\subsection{Independent Variables}

In light of our focus on the link between recent immigration, religious contextual characteristics, and violent crime, we include several key independent variables. First, we include a measure of the percent foreign born, defined as the proportion of the total population that is foreign born (hereafter, referred to interchangeably as immigration and immigrant presence). We use this measure because a careful review of prior literature demonstrates that this is one of the most common measures used to delineate the relative presence of foreign-born arrivals (Ousey and Kubrin 2018). Second, following prior research on religion and crime at the macro-level, we utilize three measures of religious adherence: mainline (Protestant) adherence, evangelical (Protestant) adherence, and Catholic adherence, with each defined as the percentage of the total population of the county that adheres to each religious tradition (see also footnote 1$)^{6}$

remain the same regardless of how we classify communities by their recent histories of immigrant settlement (see our supplemental models and robustness checks section).

5 Because we rely on three years of data (2009-2011), there are relatively few counties reporting zero offenses (only 128 out of 1359 - or about $9 \%$-report zero values for homicide). Diagnostic tests regarding the appropriateness of zero-inflated models revealed that standard negative binomial models were more appropriate.

6 Relevant for our discussion of key religious contextual measures, we rely on estimates of adherents because (a) including only full members misses a large proportion of the religiously-affiliated population who might help to exert social control in the community; (b) prior research on religious contexts has almost exclusively used counts of adherents (e.g., Lee 2008; Lee and Bartkowski 2004; Ulmer and Harris 2013); and (c) membership is determined by the by-laws of each participating congregation, making the estimation of the member population sensitive to the particularities of congregations present to a greater degree than the measuring the adherent population (Jones et al. 2002). 
In addition to our religious contextual variables, we include several measures to control for social and demographic characteristics of counties that may be linked to immigration, religious adherence, and violence. To account for county socioeconomic conditions, we created a concentrated disadvantage index using principal components analysis to combine four commonly used disadvantage indicators (see Land et al. 1990; Harris and Feldmeyer 2013): poverty (percentage of population below the poverty line), unemployment (percentage of the civilian labor force aged 16-59 years that is unemployed), female headship (percentage of families with children under 18 years headed by a female), and low education (percentage of residents aged 25+ years without a high school degree). In addition, because of their demonstrated relevance in previous studies, we include as controls: residential mobility (percentage of households that experienced housing turnover during the 2005-2010 period) and an entropy measure of racial/ethnic heterogeneity of the county population (Reardon and Firebaugh 2002). Additionally, to capture segregation/integration between immigrants and native-born residents, we also included a measure of immigrant-native segregation using the index of dissimilarity (Feldmeyer et al. 2015; Massey and Denton 1988). To separate out the impact of religious adherence from political conservatism, we also included a measure of the percent Republican voting within the county (out of all votes cast in the 2008 presidential election). Finally, as basic demographic controls, we also included variables for the logged population density, percent urban, logged police per capita as a control for variations across counties in law enforcement activity, and region dummy variables (the latter four measures are included in analyses but not shown given space constraints; see note in Table 2).

\subsection{Analytic Techniques}

Our analysis unfolds as follows. First, we present descriptive statistics with an emphasis on mean levels of violence, immigration, religious adherence, and our other key measures across traditional, emerging, and other immigrant locales. Second, because of the skewed distribution of known homicide, robbery, and aggravated assault incidents across counties and their over-dispersion (see Osgood 2000), we construct a series of multivariate negative binomial regression models regressing each of our three religious adherence measures-mainline Protestant, evangelical Protestant, and Catholic-on each violent offense along with our key independent variables. Each model includes exposure terms for the population at risk (aged 18-64 years) and state-clustered standard errors to account for variation across counties nested within the same states.

\subsection{Primary Results}

Table 1 displays the means and standard deviations for all of our key dependent and independent variables broken out separately for emerging, traditional, and other immigrant destinations. We noted, first, that there are very small differences in mean violence rates across the different types of immigrant destinations. Only aggravated assault rates (per 100,000 as shown in Table 1) are somewhat greater in emerging and other immigrant destinations (means of 1436.05 and 1434.22, respectively) than in traditional immigrant settlements (mean of 1122.86), a difference of over 20 percent. Both homicide and robbery rates differ by less than $10 \%$ across destination types.

Second, religious adherence differs substantially across destination type. Where evangelical Protestants make up the largest adherent share in both emerging and other immigrant destinations (means of 26.86 and 24.18 percent of the population, respectively), evangelical Protestant adherence in traditional immigrant destinations is substantially lower as a share of the overall population (mean of 15.23 percent). Instead, Catholic adherents, on average, represent the largest single adherent group in traditional destinations (mean of 19.59 percent), whereas Catholic adherence in emerging destinations (mean of 9.54 percent) lags behind even mainline Protestantism (mean of 11.33 percent). Likewise, other immigrant destination communities have, on average, less Catholic adherence (mean of 11.52 percent) than traditional immigrant settlement communities. 
Table 1. Means and standard deviations (in parentheses) for key variables by destination type.

\begin{tabular}{|c|c|c|c|}
\hline & Emerging & Traditional & Other \\
\hline \multicolumn{4}{|l|}{ Dependent Variables: ${ }^{\text {a }}$} \\
\hline \multirow[t]{2}{*}{ Homicide Rate } & 4.49 & 4.76 & 4.93 \\
\hline & $(4.27)$ & $(5.78)$ & $(3.75)$ \\
\hline \multirow[t]{2}{*}{ Robbery Rate } & 106.66 & 114.44 & 118.74 \\
\hline & $(111.49)$ & $(119.38)$ & $(90.42)$ \\
\hline Aggravated Assault Rate & 1436.05 & 1122.86 & 1434.22 \\
\hline Religious Contextual Variables: & $(1039.43)$ & $(705.50)$ & $(837.77)$ \\
\hline \multirow[t]{2}{*}{$\%$ Catholic } & 9.54 & 19.59 & 11.52 \\
\hline & $(10.18)$ & $(13.56)$ & $(11.34)$ \\
\hline \multirow[t]{2}{*}{$\%$ Evangelical Protestant } & 26.86 & 15.23 & 24.18 \\
\hline & $(12.28)$ & $(12.07)$ & $(15.61)$ \\
\hline$\%$ Mainline Protestant & 11.33 & 6.85 & 9.89 \\
\hline Control Variables: & $(7.46)$ & $(4.94)$ & $(5.93)$ \\
\hline \multirow{2}{*}{ \% Foreign Born } & 8.12 & 13.14 & 4.58 \\
\hline & $(2.93)$ & $(8.63)$ & $(3.22)$ \\
\hline \multirow[t]{2}{*}{$\%$ Poverty } & 15.16 & 14.44 & 14.46 \\
\hline & $(5.16)$ & $(6.28)$ & $(5.21)$ \\
\hline \multirow[t]{2}{*}{ \% Unemployed } & 4.71 & 4.67 & 4.62 \\
\hline & $(1.24)$ & $(1.26)$ & $(1.30)$ \\
\hline \multirow[t]{2}{*}{ \% Female Headship } & 12.01 & 12.28 & 12.01 \\
\hline & $(3.80)$ & $(3.86)$ & $(3.82)$ \\
\hline \multirow[t]{2}{*}{ \% Without High School Degree } & 18.29 & 15.40 & 15.22 \\
\hline & $(6.53)$ & $(8.23)$ & $(5.52)$ \\
\hline \multirow[t]{2}{*}{ Mobility } & 15.00 & 17.09 & 15.49 \\
\hline & $(3.76)$ & $(5.53)$ & $(4.15)$ \\
\hline \multirow[t]{2}{*}{ Immigrant-Native Segregation } & 32.93 & 26.85 & 31.24 \\
\hline & $(9.91)$ & $(8.31)$ & $(8.98)$ \\
\hline \multirow[t]{2}{*}{ Racial/Ethnic Diversity } & 0.56 & 0.57 & 0.41 \\
\hline & $(0.19)$ & $(0.21)$ & $(0.22)$ \\
\hline \multirow[t]{2}{*}{$\%$ Republican } & 58.42 & 49.77 & 56.46 \\
\hline & $(12.23)$ & $(14.96)$ & (12.53) \\
\hline \multirow[t]{2}{*}{$\%$ Urban } & 52.20 & 75.19 & 57.07 \\
\hline & $(25.76)$ & $(22.49)$ & $(22.08)$ \\
\hline$N$ & 135 & 575 & 649 \\
\hline
\end{tabular}

\footnotetext{
${ }^{a}$ Violence rates are displayed for ease of interpretation but all subsequent models use offense counts.
}

Third, we also found some important differences in macro-social characteristics across immigrant destinations. Emerging immigrant communities have higher mean levels of poverty and educational deficits (i.e., the percentage of the population without a high school degree) than traditional and other destinations, which is broadly consistent with the profile of new immigrants drawn to low-skill labor opportunities in these locales (Shihadeh and Barranco 2010). Additionally, emerging destinations have higher levels of segregation and Republican voters as of the 2008 election cycle. In contrast, and as expected given their different histories of settlement, traditional immigrant destinations have larger foreign-born population shares (mean of 13.14) than both emerging (mean of 8.12) and other immigrant destinations (mean of 4.58). At the same time, traditional destinations tend to have somewhat higher residential mobility and are significantly more urban than any other immigrant community type.

We turn now to the primary focus of the current study and examine the ways in which adherence to each religious tradition is associated with violence across different immigrant contexts. To that end, Table 2 displays the results of our negative binomial regression models predicting homicide, robbery, and assault in emerging (panel A), traditional (panel B), and other immigrant destinations (panel C). Our focus here is on differences across religious traditions in their associations with violence, particularly as they vary by immigrant settlement type. 
First, we found that, among our religious adherence measures, only Catholic adherence has a consistent, statistically significant, and negative association with violence. Furthermore, the protective effect of Catholic adherence is found exclusively in traditional immigrant communities. Across all three violence types, greater Catholic adherence is associated with lower incidence of homicide $(b=-0.007$, $p<0.01)$, robbery $(b=-0.007, p<0.05)$, and assault $(b=-0.004, p<0.05)$ in traditional immigrant communities, but has no association with violence in emerging destinations and is negatively associated with assault (but not homicide or robbery) in other immigrant settlements. In contrast, evangelical adherence is positively associated with both robbery and assault, but only in traditional immigrant destinations $(p<0.05)$. Religious adherence to any mainline Protestant groups has no significant effect on any forms of violence examined here. Similarly, we found no significant relationships between any form of religious adherence and crime (net of other key variables) in emerging destinations.

Second, the relative size of the foreign-born population is (when statistically significant) universally associated with lower rates of crime. This finding dovetails with a now sizeable literature showing that immigrants are generally less crime-prone than the domestic population (Bui 2009; Greenman and Xie 2008) and that immigrant concentration is commonly associated with lower macro-level rates of crime (see Ousey and Kubrin (2018) for a meta-analytic review). In short, there is little evidence that immigration coincides with elevated incidence of known violence, regardless of a community's history of immigrant settlement. However, we do note that emerging destinations show somewhat less consistent effects of immigrant concentration on violence (significant effects for robbery only) than either traditional or other destination counties.

Third, among our other control variables, disadvantage is the single most consistent and robust predictor: where disadvantages combine in a community, violence is more common regardless of immigrant settlement history. Greater racial/ethnic diversity is also significantly associated with higher rates of violence in all models (except for assault in emerging destinations). Residential mobility is associated with increased levels of robbery and assault, but only in traditional immigrant destinations, whereas percent urban is fairly consistently associated with robbery and assault (but not homicide), regardless of destination type. Finally, immigrant segregation from the native-born population impacts violence uniquely depending on the immigrant settlement type: greater levels of immigrant segregation from the native-born populations appears to protect against all types of violence in traditional destinations (perhaps exhibiting an ethnic enclave effect), but greater segregation contributes to more robberies in other destinations and more assaults in emerging locales. Notably, the consistency of our control variables and the strength of their associations with violence often surpass those of our religious contextual measures. 
Table 2. Negative binomial regression of religious adherence and controls on violence in (A) emerging, (B) traditional, and (C) other immigrant destinations.

\begin{tabular}{|c|c|c|c|c|c|c|c|c|c|}
\hline & \multicolumn{3}{|c|}{ (A) Emerging Destinations $(N=135)$} & \multicolumn{3}{|c|}{ (B) Traditional Destinations $(N=575)$} & \multicolumn{3}{|c|}{ (C) Other Destinations $(N=649)$} \\
\hline & Homicide & Robbery & Assault & Homicide & Robbery & Assault & Homicide & Robbery & Assault \\
\hline Religious Variables: & & & & & & & & & \\
\hline \% Catholic & $\begin{array}{c}0.007 \\
(0.009)\end{array}$ & $\begin{array}{l}-0.002 \\
(0.007)\end{array}$ & $\begin{array}{l}-0.001 \\
(0.006)\end{array}$ & $\begin{array}{c}-0.007 * * \\
(0.002)\end{array}$ & $\begin{array}{c}-0.007^{*} \\
(0.003)\end{array}$ & $\begin{array}{c}-0.004^{*} \\
(0.002)\end{array}$ & $\begin{array}{l}-0.003 \\
(0.003)\end{array}$ & $\begin{array}{l}-0.001 \\
(0.002)\end{array}$ & $\begin{array}{c}-0.005 * \\
(0.002)\end{array}$ \\
\hline$\%$ Evangelical Protestant & $\begin{array}{l}-0.004 \\
(0.007)\end{array}$ & $\begin{array}{l}-0.004 \\
(0.006)\end{array}$ & $\begin{array}{l}-0.002 \\
(0.006)\end{array}$ & $\begin{array}{l}-0.005 \\
(0.004)\end{array}$ & $\begin{array}{l}0.009 * \\
(0.004)\end{array}$ & $\begin{array}{c}0.009 * * \\
(0.003)\end{array}$ & $\begin{array}{c}0.002 \\
(0.003)\end{array}$ & $\begin{array}{c}0.003 \\
(0.002)\end{array}$ & $\begin{array}{l}-0.001 \\
(0.002)\end{array}$ \\
\hline $\begin{array}{l}\text { \% Mainline Protestant } \\
\text { Control Variables: }\end{array}$ & $\begin{array}{c}0.012 \\
(0.011)\end{array}$ & $\begin{array}{c}0.005 \\
(0.009)\end{array}$ & $\begin{array}{l}-0.005 \\
(0.008)\end{array}$ & $\begin{array}{c}0.004 \\
(0.009)\end{array}$ & $\begin{array}{l}-0.007 \\
(0.009)\end{array}$ & $\begin{array}{l}-0.008 \\
(0.008)\end{array}$ & $\begin{array}{c}0.005 \\
(0.006)\end{array}$ & $\begin{array}{c}0.007 \\
(0.005)\end{array}$ & $\begin{array}{l}-0.002 \\
(0.004)\end{array}$ \\
\hline \% Foreign Born & $\begin{array}{l}-0.055 \\
(0.030)\end{array}$ & $\begin{array}{c}-0.067^{* *} \\
(0.020)\end{array}$ & $\begin{array}{l}-0.031 \\
(0.018)\end{array}$ & $\begin{array}{c}-0.027 * * * \\
(0.005)\end{array}$ & $\begin{array}{c}-0.010 \text { * } \\
(0.005)\end{array}$ & $\begin{array}{l}-0.007 \\
(0.004)\end{array}$ & $\begin{array}{c}-0.045^{* * *} \\
(0.009)\end{array}$ & $\begin{array}{c}-0.041^{* * *} \\
(0.010)\end{array}$ & $\begin{array}{c}-0.028^{* * *} \\
(0.008)\end{array}$ \\
\hline Disadvantage & $\begin{array}{c}0.299 * * * \\
(0.082)\end{array}$ & $\begin{array}{c}0.281 \text { *** } \\
(.061)\end{array}$ & $\begin{array}{c}0.154 * * \\
(0.058)\end{array}$ & $\begin{array}{c}0.357^{* * *} \\
(0.027)\end{array}$ & $\begin{array}{c}0.162 * * * \\
(0.029)\end{array}$ & $\begin{array}{c}0.120 * * * \\
(0.026)\end{array}$ & $\begin{array}{c}0.281^{* * *} \\
(0.032)\end{array}$ & $\begin{array}{c}0.281^{* * *} \\
(0.029)\end{array}$ & $\begin{array}{c}0.184^{* * *} \\
(0.025)\end{array}$ \\
\hline Mobility & $\begin{array}{c}-0.018 \\
(0.019)\end{array}$ & $\begin{array}{l}-0.021 \\
(0.015)\end{array}$ & $\begin{array}{l}-0.004 \\
(0.014)\end{array}$ & $\begin{array}{r}-0.005 \\
(0.008)\end{array}$ & $\begin{array}{c}0.042^{* * *} \\
(0.007)\end{array}$ & $\begin{array}{c}0.038^{* * *} \\
(0.006)\end{array}$ & $\begin{array}{c}-0.016^{*} \\
(0.007)\end{array}$ & $\begin{array}{l}-0.005 \\
(0.006)\end{array}$ & $\begin{array}{l}-0.003 \\
(0.006)\end{array}$ \\
\hline Immigrant-Native Segregation & $\begin{array}{l}-0.011 \\
(0.829)\end{array}$ & $\begin{array}{c}0.679 \\
(0.587)\end{array}$ & $\begin{array}{l}1.318^{*} \\
(0.524)\end{array}$ & $\begin{array}{c}-1.268 \text { ** } \\
(0.198)\end{array}$ & $\begin{array}{c}-1.319 * * \\
(0.469)\end{array}$ & $\begin{array}{c}-0.687^{*} \\
(0.396)\end{array}$ & $\begin{array}{c}0.390 \\
(0.350)\end{array}$ & $\begin{array}{c}0.746^{* *} \\
(0.281)\end{array}$ & $\begin{array}{l}-0.259 \\
(0.252)\end{array}$ \\
\hline Racial/Ethnic Diversity & $\begin{array}{l}1.817^{* *} \\
(0.614)\end{array}$ & $\begin{array}{c}2.084^{* * *} \\
(0.434)\end{array}$ & $\begin{array}{c}0.579 \\
(0.388)\end{array}$ & $\begin{array}{c}1.629 * * * \\
(0.198)\end{array}$ & $\begin{array}{c}1.455^{* * *} \\
(0.213)\end{array}$ & $\begin{array}{c}0.648^{* * *} \\
(0.185)\end{array}$ & $\begin{array}{c}1.170 * * * \\
(0.203)\end{array}$ & $\begin{array}{c}1.390^{* * *} \\
(0.171)\end{array}$ & $\begin{array}{l}0.410 * * \\
(0.157)\end{array}$ \\
\hline$\%$ Republican & $\begin{array}{c}0.006 \\
(0.007)\end{array}$ & $\begin{array}{l}-0.007 \\
(0.005)\end{array}$ & $\begin{array}{c}0.003 \\
(0.005)\end{array}$ & $\begin{array}{l}-0.001 \\
(0.003)\end{array}$ & $\begin{array}{c}0.002 \\
(0.003)\end{array}$ & $\begin{array}{c}0.003 \\
(0.002)\end{array}$ & $\begin{array}{c}-0.005^{*} \\
(0.003)\end{array}$ & $\begin{array}{l}-0.004 \\
(0.002)\end{array}$ & $\begin{array}{c}0.003 \\
(0.002)\end{array}$ \\
\hline AIC & 483.28 & 1030.51 & 1945.21 & 2945.52 & 6222.02 & 9411.753 & 2188.35 & 5217.76 & 9606.53 \\
\hline
\end{tabular}

Note: Standard errors are in parentheses. All models include controls for percent urban, logged population size, population density, police per capita, regional dummy variables, and state-clustered standard errors. All variance inflation factors (VIFs) are below $4.8 .{ }^{*} p<0.05,{ }^{* *} p<0.01,{ }^{* * *} p<0.001$ 


\subsection{Supplemental Models}

In addition to our primary models, we also conducted a number of robustness checks and constructed supplemental models. Specifically, (a) we explored alternative portioning of counties whereby traditional destinations were defined as those with immigrant growth rates exceeding the national average in 1980,1990, and 2000, while emerging destinations were reclassified as those with growth rates lower than the national average in 1980 and 1990, but greater than the national average in 2000; similarly, we constructed models that (b) used logarithmically transformed crime rates rather than counts; (c) included immigrant isolation rather than unevenness as a measure of segregation (Massey and Denton 1988); and (d) included interaction terms for the conditional effect of religious adherence by disadvantage (see for example Harris and Feldmeyer (2015)). All models provided substantively similar results and the interaction terms were non-significant across all destination types (available upon request).

\section{Discussion}

Our goal here was to address an underexamined issue both within the religion-crime literature broadly, and immigration-crime research specifically: whether different forms of religious adherence are associated with crime and violence uniquely across immigrant settlement contexts. The United States has seen recent demographic shifts of the foreign born toward "emerging" destinations within the interior of the United States and to suburban/rural locations even within traditional settlement states (Singer 2004). As such, there is a need to explore the role played by religious organizations and their adherents in providing social capital, norms and values, and social control in ways that might buffer against crime in different communities.

Overall, we found that religious traditions varied in their relationship with known violence across destination types. On the one hand, Catholic adherence was protective against crime (net of controls) only in traditional immigrant destinations. On the other hand, evangelical Protestant adherence was associated with higher levels of robbery and aggravated assault in the same locales. Religious adherence had no links to violence in emerging immigrant destinations.

Broadly, our results suggest, first, that religion plays an important role in shaping crime in immigrant communities above and beyond the more traditional structural measures employed throughout macro-level social science inquiry. However, not all contexts are the same. Theoretically, for example, our findings lend more support to perspectives emphasizing the bridging social capital, systemic social control, and social bonds engendered by widespread Catholic adherence (Putnam 2000). However, these effects appear to be limited to traditional immigrant communities, which are more likely to offer a large "critical mass" of adherents that can help establish the types of civic outreach and social controls needed for community crime control. Likewise, that evangelical adherence produces the kinds of bonding capital and in-group/out-group insularity thought to elevate rates of crime is bolstered by our findings, but only in communities without substantial histories of immigration. In short, the impact of religion on crime depends greatly on the kind of community in question.

Second, relative to the immigration-crime literature, our findings suggest that religious milieus offer mixed resources to immigrant communities depending on the relative presence of specific religious traditions. Our findings are consistent with prior research showing that Catholic adherence is linked to lower rates of crime and violence (e.g., Beyerlein and Hipp 2005; Harris and Feldmeyer 2015), as well as those studies finding evangelical adherence to be associated with higher rates of crime (e.g., Beyerlein and Hipp 2005; Shihadeh and Winters 2010). Critically, however, such relationships are only observed in traditional immigrant locales-the kinds of large, metropolitan, and historical points of foreign-born settlement that still receive the largest share of newly arriving immigrants today.

Third, we observed that the relative size of the foreign-born population was associated with lower rates of crime, regardless of where immigrants settle. Such a finding is consistent with a now sizeable literature within the broader social sciences (Ousey and Kubrin 2018). Put simply, immigration coincides with lower rates of known violence, regardless of a community's history of immigrant 
settlement (though emerging destinations show somewhat less consistent effects of immigration on violence).

Finally, many of our key control variables included in each of the models were robustly associated with violence, often having more impactful associations with violence than several of the religious contextual measures. This is not altogether surprising given that prior research has consistently found these variables to be among the strongest and most consistent predictors of macro-level crime rates (Pratt and Cullen 2005). For example, disadvantage was the single most consistent positively-associated predictor, net of religious milieu characteristics and other key controls. Likewise, greater racial/ethnic diversity was significantly associated with higher rates of violence in nearly all cases, while residential mobility was associated with increased levels of robbery and assault in traditional immigrant destinations. Percent urban was also consistently associated with robbery and assault, regardless of destination type. Interestingly, immigrant segregation from the native-born population was positively linked to violence in emerging and other types of immigrant destinations, but negatively associated with violence in traditional immigrant locales (even while overall racial/ethnic diversity was positively associated). This latter finding may reflect the protective formation of ethnic enclaves in established settlement locales (see for example, Feldmeyer et al. (2015)), despite the destabilizing and criminogenic impact of racial heterogeneity more broadly. In contrast, segregation of the foreign born from the native population provides no such benefits in emerging and other destinations-and, in fact, is linked to higher rates of crime-because fewer co-ethnics and cultural resources are available in these more isolated circumstances with little history of immigrant assimilation and incorporation. In sum, our findings mirror prior studies in showing that factors like disadvantage, heterogeneity, and residential mobility are among the primary sources of macro-level crime rates (Steffensmeier et al. 2010). More importantly, our findings go beyond prior work and extend this line of scholarship by showing that religious adherence and its intersection with immigrant communities is also an essential, and to date, understudied, part of the macro-level story of communities and crime.

Although we see our study as advancing research at the critical intersection of immigration, religion, and crime at the macro-level, we also recognize a number of limitations that warrant attention in future research. For example, it is beyond the scope of the current study to explore the impact of tradition-specific adherence on race/ethnic-disaggregated crime. Given the data constraints in doing so (e.g., limited types of crime, narrow geographic scope, etc.), questions remain as to whether religious adherence affects violence (or other forms of crime) equally across all race/ethnic groups in each type of immigrant destination. Likewise, scholarship in this area would benefit greatly from more nuanced religious adherence measures, including those reflecting the degree of personal participation and religiosity, as well as measurable religious characteristics at other units of analysis (e.g., cities, census places, or even neighborhoods). As we acknowledged in our methods section, these alternative dimensions of religious participation are not available across a large number of units at the present time, but would substantially bolster the unfolding story of how religion manifests in different types of locales, including immigrant communities.

Immigration remains a hot button issue across our nation, increasingly so after the 2016 presidential election. Amidst concern about how immigrant flows have reshaped communities and impacted social problems like crime, research directed toward immigration and the types of structural and cultural processes unfolding around (and in conjunction with) it will remain central to informing the broader public debate. However, the current findings reaffirm the growing consensus in social science research that these concerns about immigrant crime are often misplaced. Rather than increasing crime and violence, it appears that traditional immigrant settlement communities are home to strong networks of Catholic adherents that help to reduce, not generate, rates of serious violent crime.

Author Contributions: The idea for this research was conceived by Casey T. Harris and Ben Feldmeyer. Data collection and analysis was performed by Casey T. Harris and Raymond Barranco. Composition of the manuscript was completed by all three authors.

Conflicts of Interest: The authors declare no conflicts of interest. 
Funding Sources: This research was supported by National Institute of Justice grant NIJ 2015-R2-CX-0038.

\section{References}

Association of Statisticians of American Religious Bodies. 2012. Association of Statisticians of American Religious Bodies. Religious Congregations and Membership Survey: Methods of Data Collection. Available online: http:/ / www.rcms2010.org (accessed on 5 February 2018).

Beyerlein, Kraig, and John Hipp. 2005. Social capital, too much of a good thing? American religious traditions and community crime. Social Forces 84: 995-1006. [CrossRef]

Bui, Hoan N. 2009. Parent-child conflicts, school troubles, and differences in delinquency across immigration generations. Crime \& Delinquency 55: 412-41.

Bursik, Robert J., and Harold G. Grasmick. 1993. Neighborhoods and Crime: The Dimensions of Effective Community Control. San Francisco: Jossey-Bass Inc.

Chamlin, Mitchell B., and John K. Cochran. 1995. Assessing Messner and Rosenfeld's institutional anomie theory: A partial test. Criminology 33: 411-30. [CrossRef]

Desmond, Scott, Kristopher Morgan, and George Kikuchi. 2010. Congregations and crime: Is the spatial distribution of congregations associated with neighborhood crime rates? Journal for the Scientific Study of Religion 49: 37-55. [CrossRef]

Ellison, Christopher G., Jeffrey Burr, and Patricia McCall. 2003. The enduring puzzle of southern homicide: Is regional religious culture the missing piece? Homicide Studies 7: 326-52. [CrossRef]

Federal Bureau of Investigation. 2010. Crime in the United States, 2010. Washington: Department of Justice, 2010.

Feldmeyer, Ben, Casey T. Harris, and Jennifer Scroggins. 2015. Enclaves of opportunity or "ghettos of last Rresort?" Assessing the effects of immigrant segregation on violent crime rates. Social Science Research 52: 1-17. [CrossRef] [PubMed]

Finke, Roger, and Christopher Scheitle. 2005. Accounting for the uncounted: Computing correctives for the 2000 RCMS data. Review of Religious Research 47: 5-22. [CrossRef]

Frey, William H. 2006. Diversity spreads out: Metropolitan shifts in Hispanic, Asian, and Black populations since 2000. In Metropolitan Policy Program Living Census Series (March 2006). Washington: Brookings Institute, March 20.

Greenman, Emily, and Yu Xie. 2008. Is assimilation theory dead? The effect of assimilation on adolescent well-being. Social Science Research 37: 109-37. [CrossRef] [PubMed]

Harris, Casey, and Ben Feldmeyer. 2013. Latino immigration and White, Black, and Latino violent crime: A comparison of traditional and non-traditional immigrant destinations. Social Science Research 42: 202-16. [CrossRef] [PubMed]

Harris, Casey, and Ben Feldmeyer. 2015. A shot of morality? Hispanic immigration, religious contextual characteristics, and violence. Sociological Spectrum 35: 229-53. [CrossRef]

Hirschi, Travis, and Rodney Stark. 1969. Hellfire and delinquency. Social Problems 17: 202-13. [CrossRef]

Hirschman, Charles. 2004. The role of religion in the origins and adaptation of immigrant groups in the United States. International Migration Review 38: 1206-33. [CrossRef]

Johnson, Byron R., David Larson, Spencer D. Li, and Sung Joon Jang. 2000. Escaping from the crime of inner cities: Church attendance and religious salience among disadvantaged youth. Justice Quarterly 17: 377-91. [CrossRef]

Jones, Dale E., Sherri Doty, James E. Horsch, Richard Houseal, Mac Lynn, John P. Marcum, Kenneth M. Sanchagrin, and Richard H. Taylor. 2002. Religious Congregations and Membership in the United States 2000: An Enumeration by Region, State and County Based on Data Reported by 149 Religious Bodies. Nashville: Glenmary Research Center.

Lafree, Gary, Eric P. Baumer, and Robert O'Brien. 2008. Still separate and unequal: A city-level analysis of the Black-White gap in homicide arrests since 1960. American Sociological Review 75: 75-100. [CrossRef]

Land, Kenneth, Patricia McCall, and Lawrence Cohen. 1990. Structural covariates of homicide rates: Are there any invariances across time and social space? American Journal of Sociology 95: 922-63. [CrossRef]

Lee, Matthew R. 2006. The religious institutional base and violent crime in rural areas. Journal for the Scientific Study of Religion 45: 309-24. [CrossRef]

Lee, Matthew R. 2008. Civic Community in the hinterland: Toward a theory of rural social structure and violence. Criminology 46: 447-78. [CrossRef] 
Lee, Matthew R., and John P. Bartkowski. 2004. Love thy neighbor? Moral communities, civic engagement, and juvenile homicide in rural areas. Social Forces 82: 1001-35. [CrossRef]

Lee, Matthew T., Ramiro Martinez Jr., and Richard Rosenfeld. 2001. Does immigration increase homicide? Negative evidence from three border cities. The Sociological Quarterly 42: 559-80. [CrossRef]

Lichter, Daniel T., and Kenneth M. Johnson. 2009. Immigrant gateways and Hispanic migration to new destinations. International Migration Review 43: 496-518. [CrossRef]

Lyons, Christopher J., Maria B. Velez, and Wayne A. Santoro. 2013. Neighborhood immigration, violence, and city-level immigrant political opportunities. American Sociological Review 78: 604-32. [CrossRef]

Martinez, Ramiro, Jr. 2002. Latino Homicide: Immigration, Violence, and Community. New York: Routledge.

Martinez, Ramiro, Jr., Jacob I. Stowell, and Matthew T. Lee. 2010. Immigration and crime in an era of transformation: A longitudinal analysis of homicides in San Diego neighborhoods, 1980-2000. Criminology 48: 797-829. [CrossRef]

Massey, Douglas S., and Nancy A. Denton. 1988. The dimensions of residential segregation. Social Forces 67: 281-315. [CrossRef]

Merton, Robert K. 1938. Social structure and anomie. American Sociological Review 3: 672-82. [CrossRef]

Messner, Steven, and Richard Rosenfeld. 1994. Crime and the American Dream. Belmont: Wadsworth.

Navarro-Rivera, Juhem, Barry A. Kosmin, and Ariela Keysar. 2010. U.S. Latino Religious Identification 1990-2008: Growth, Diversity \& Transformation. Trinity College Program on Public Values Report; Hartford: Institute for the Study of Secularism in Society and Culture.

Ogsood, D. Wayne, and Jeff M. Chambers. 2000. Social disorganization outside the metropolis: An analysis of rural youth violence. Criminology 38: 81-116.

Osgood, D. Wayne. 2000. Poisson-based regression analysis of aggregate crime rates. Journal of Quantitative Criminology 16: 21-43. [CrossRef]

Ousey, Graham C., and Charis E. Kubrin. 2009. Exploring the connection between immigration and violent crime rates in U.S. cities, 1980-2000. Social Problems 56: 447-73. [CrossRef]

Ousey, Graham C., and Charis E. Kubrin. 2018. Immigration and crime: Assessing a contentious issue. Annual Review of Criminology 1: 63-84. [CrossRef]

Painter-Davis, Noah. 2016. Immigration effects on violence contextualized: The role of immigrant destination type and race/ethnicity. Sociological Perspectives 59: 130-52. [CrossRef]

Peterson, Ruth, and Lauren Krivo. 2005. Macrostructural analyses of race, ethnicity, and violent crime: Recent lessons and new directions for research. Annual Review of Sociology 31: 331-56. [CrossRef]

Pew Hispanic Center. 2007. The Religious Affiliation of U.S. Immigrants: Majority Christian, Rising Share of Other Faiths. Washington: Pew Hispanic Center.

Pew Hispanic Center. 2014. The Shifting Religious Identity of Latinos in the United States. Washington: Pew Hispanic Center.

Portes, Alejandro, and Gordon Rumbaut. 2006. Immigrant America: A Portrait. Berkeley: University of California Press.

Pratt, Travis, and Frances Cullen. 2005. Assessing macro-level predictors and theories of crime: A meta-analysis. In Crime and Justice: A Review of Research. Edited by Michael Tonry. Chicago: University of Chicago Press, pp. 373-450.

Putnam, Robert D. 2000. Bowling Alone: The Collapse and Revival of American Community. New York: Simon and Schuster.

Ramey, David M. 2013. Immigrant revitalization and neighborhood violent crime in established and new destination cities. Social Forces 92: 597-629. [CrossRef]

Reardon, Sean F., and Glenn Firebaugh. 2002. Measures of multigroup segregation. Sociological Methodology 32: 33-67. [CrossRef]

Sampson, Robert J. 2008. Rethinking crime and immigration. Contexts 7: 28-33. [CrossRef]

Sampson, Robert J. 2013. The place of context: A theory and strategy for criminology's hard problems. Criminology 51: 1-31. [CrossRef]

Sampson, Robert J., and Stephen W. Raudenbush. 1999. Systematic social observation of public spaces: A new look at disorder in urban neighborhoods. American Journal of Sociology 105: 603-51. [CrossRef]

Shihadeh, Edward S., and Raymond Barranco. 2010. Latino employment and Black violence: The unintended consequence of U.S. immigration policy. Social Forces 88: 1393-420. [CrossRef] 
Shihadeh, Edward S., and Raymond Barranco. 2013. The imperative of place: Homicide and the new Latino migration. The Sociological Quarterly 54: 81-104. [CrossRef]

Shihadeh, Edward, and Lisa Winters. 2010. Church, place, and crime: Latinos and homicide in new destinations. Sociological Inquiry 80: 629-49. [CrossRef]

Singer, Audrey. 2004. The Rise of New Immigrant Gateways. Washington: Brookings Institute.

Smith, Christian. 2003. Moral, Believing Animals: Human Personhood and Culture. New York: Oxford University Press.

Steensland, Brian, Jerry Z. Park, Mark D. Regnerus, Lynn D. Robinson, W. Bradford Wilcox, and Robert D. Woodberry. 2000. The measure of American religion: Toward improving the state of the art. Social Forces 79: 291-318. [CrossRef]

Steffensmeier, Darrell, and Dana Haynie. 2000. Gender, structural disadvantage, and urban crime: Do macro-social variables also explain female offending rates. Criminology 38: 403-38. [CrossRef]

Steffensmeier, Darrel, Jeffery Ulmer, Ben Feldmeyer, and Casey T. Harris. 2010. Scope and conceptual issues in testing the race-crime invariance thesis: Black, white, and Hispanic comparisons. Criminology 48: 1133-69. [CrossRef] [PubMed]

Terrazas, Aaron. 2011. Immigrants in New Destination States. Washington: Migration Policy Institute. Available online: https:/ / www.migrationpolicy.org/article/immigrants-new-destination-states (accessed on 12 March 2018).

Tolbert, Charles M., Thomas A. Lyson, and Michael D. Irwin. 1998. Local capitalism, civic engagement, and socioeconomic well-being. Social Forces 77: 401-27. [CrossRef]

Tolbert, Charles M., Michael D. Irwin, Thomas A. Lyson, and Alfred R. Nucci. 2002. Civic community in small-town America: How civic welfare is influenced by local capitalism and civic engagement. Rural Sociology 57: 90-113. [CrossRef]

Ulmer, Jeffery T., and Casey T. Harris. 2013. Race and the religious contexts of violence: Linking religion and White, Black, and Latino violent crime. The Sociological Quarterly 54: 610-46. [CrossRef] [PubMed]

Van Tubergen, Frank. 2006. Religious affiliation and attendance among immigrants in eight Western countries: Individual and contextual effects. Journal for the Scientific Study of Religion 45: 1-22. [CrossRef]

Wadsworth, Tim. 2010. Is immigration responsible for the crime drop? An assessment of the influence of immigration on changes in violent crime between 1990 and 2000. Social Science Quarterly 91: 531-53. [CrossRef]

Yang, Fengang, and Helen Ebaugh. 2001. Transformations in new immigrant religions and their global implications. American Sociological Review 66: 269-88. [CrossRef]

Zuniga, Victor, and Ruben Hernandez-Leon. 2005. New Destinations: Mexican Immigration in the United States. New York: Russell Sage. 